\title{
New Historicism in Translation Studies
}

\author{
Mir Mohammad Khadem-Nabi (Corresponding Author) \\ Shahid Beheshti University \\ E-mail: mi.khademnabi@gmail.com \\ Elaheh Gharesoufloo \\ Azad Tehran University, Central Branch, Iran \\ E-mail: e.gharesoufloo@yahoo.com
}

Received: 18-04-2014

doi:10.7575/aiac.ijalel.v.3n.6p.29
Accepted: 14-06-2014

Published: 01-11-2014

URL: http://dx.doi.org/10.7575/aiac.ijalel.v.3n.6p.29

\begin{abstract}
Translation Studies has moved from linguistically oriented approaches to a historicist one. This is evident in many recent publications, and has brought about new trends in Translation Studies as well as in Cultural Studies. This paper is an attempt at summarizing the influence of the historicist approaches on translation. Of specific importance for this paper is New Historicism, which has poststructuralist tendencies.
\end{abstract}

Keywords: New Historicism, translation studies, cultural studies

\section{Introduction}

History, Bassnett and Lefevere assert in their edition of essays on literary translation, gave "relativity" to translation studies, and obliterated general rules which had been supposed to be eternal by translation scholars up to the 1980s (Bassnet and Lefevere, 1998: p.1). In fact, history disentangled translation from the New Critical hampers epitomized in the study of translation as purely lexical approaches. History can be formulated in different ways as regards the relationship we assign to history and translation. One of its derivations is historicism which has taken postmodernist color in new historicism. This genre of literary criticism has not been applied in its entirety to translation research; some aspects have been of use for translation researchers and theorists, and were incorporated into their work, and others were rejected maybe because of the complexity they would add to the already complex notion of translation. It is the objective of this essay to explore the relationship between these two trends. In what follows an account of new historicism that is relevant to the aspects of translation studies will be given. Then some of the translation theories that bear resemblance to the new historicist outlook will be enlarged on. These theories include textual and historical representation in translation, narratives of translation and translation historiography.

\section{Historicism and New Historicism}

Historicism is defined as understanding all cultural and literary artifacts in their historical context (Malpas, 2004: p.55). This means no cultural or literary artifact can be read without reference to the historical context in which it is produced. This view has come under criticism from different scholars including Walter Benjamin who sees two drawbacks in historicism: first, it considers past as given and unmediated by the present and secondly, it subscribes to the evolution notion of progress (Brooker, 2003: p.123). Hamilton presents a good description of the term:

Firstly, it is concerned to situate any statement - philosophical, historical, aesthetic or whatever - in its historical context. Secondly, it typically doubles back on itself to explore the extent to which any historical enterprise inevitably reflects the interests and bias of the period in which it was written. On the one hand, therefore, historicism is suspicious of the stories the past tells about itself; on the other hand, it is equally suspicious of its own partisanship. It offers up both its past and its present for ideological scrutiny. (Hamilton, 1996: p.3)

When the adjective "New" is added to historicism, it gains a new meaning. Before the poststructuralist theories of history, like Michel Foucault's skeptical thinking, acted on literary studies, most of the scholars had been subscribing quite naively to a view that "upheld a quasi-positivist belief in the objectivity and the unproblematic representability of the historical past" (Pieters, 2000: p.21). New historicism, an approach that challenges such a view, first surfaces in the 1980s and as a consequence of its skepticism toward objectivity has "a reciprocal concern with the historicity of texts and the textuality of history" (Montrose, 1998: p.781): while "textuality of history" means "no access to a full and authentic past", the "historicity of text" is "the social embedment [...] of all modes of writing" (ibid.). In sum, this approach posits an interest in history as "telling a story about the events of the past" rather than simply "the events of the past" (Selden and Brooker, 1997: p.188). 
From the perspective of historical representation we can see, following Pieters, two trends in the postmodern historicism: narrativist and heterological. He borrows the term narrativis i from Frank Ankersmit by which he "means a historiographical practice whose descriptions and interpretations of the past are characterized by an 'absolute accuracy', yet which is conscious throughout of the fact that historical descriptions and interpretations can in no way equal the object (the past itself)" (Pieters, 2000: p.24); so the historical idea is transferred from the "ontological level of the past" to the "discourse of the historical text" (ibid: p.28). The heterological trend which has psychoanalytical undertones aims to "get 'in touch with' or 'lay bare' the 'other' of history" (p.28) by analyzing which "the historian attempts to find the repressed of the past" (pp.28-29). Pieters concludes that the new historicist interest in anecdote is clearly a conjunction of these two trends. ${ }^{\text {ii }}$

New historicism has borrowed three main schemes from Foucault: discontinuity of history, history as a site of conflict, and a new way of dealing with "power" (Malpas, 2004: p.60). Discontinuity of history and the notion of conflict have led new historicists to reject the traditional historicist work in literary studies that describes a period in terms of a "closed set of overarching beliefs" iiii (p.61). Foucault's notion of power as something that emanates from everywhere and not just from the ruling classes leads to a kind of analysis whose aim is "to carefully disentangle the myriad ways in which power is produced and organized in a society or period, how it circulates in that culture to generate particular identities and institutions, and how alternative ways of thinking and being, resistances, might be made available" (ibid.).

Following poststructuralist ideas of "human behavior, practices and knowledge" as "constructs and inventions", and texts "as participating in the production of ideology and culture", this approach has it that "there is no division between text and context, or between literature and politics" (Brannigan, 1998: p.19). New historicism tries to "treat texts as a space where power relations are made visible" (p.6). Poststructuralist schools, including new historicism, "focus on language in texts of all kinds, not just literary ones, in order to expose or demystify its workings" (Diengott, 1998: p.497).

Finally, the anthropological turn new historicism takes is important: while "the past is a foreign country", as L.P. Hartley famously says, "approaching the sign system of the past", in the new historicist thinkers' view, is "analogous with anthropologists approaching the sign systems of another culture" (Brannigan, 1998: p.31). A method used by new historicist to contextualize the works they study and to shed light on the power relations, thick description is a concept in anthropology that means "descending into detail" (Geertz in Brannigan, 1998: p.35). Thick description is in close relationship with the anecdotal method that takes into account literary as well as non-literary texts (like medical, law texts).

\section{New Historicism and Translation Studies}

\subsection{General trends}

Having given a brief account of new historicism, we come to the question the whole paper is about: What is the significance of these trends in translation studies? Susan Bassnett and Andre Lefevere, two prominent theorists of translation in the cultural paradigm, believe translations "are never produced in an airlock where they, and their originals, can be checked against the tertium comparationis in the purest possible lexical chamber, untainted by power, time, or even the vagaries of culture" (Lefevere, 1995: p.7). It is a fact that translation, whether considered as a firstorder or second-order production, is a textual and discursive practice that is under the impact of the ideological and historical context in which it emerges. ${ }^{\text {iv }}$ The tertium comparationis, against which these scholars define their work, is the spirit of fully linguistic approaches to translation that take positivist stands. ${ }^{\mathrm{v}}$

New historicism with its legacy of Foucauldian interest in micro-histories and thick description has turned to case studies. Addressing the issues of literary translation studies in the descriptive paradigm, Theo Hermans asserts this point: "just as literary studies grew skeptical about grand historical narratives and discovered the micro-stories of New Historicism, descriptivists have relished the detail of individual case studies" (Hermans, 2003: p.88). This influence, of course, is an invisible one that has turned a commonsense practice among translation scholars.

Therefore, the task of a historicist translation researcher can be bringing out the workings of ideology in the context of translation or "historicize comparatism and comparatize historicism" (Coldiron, 2001: p.100). One such view can be found in Venuti's "Introduction" to Rethinking Translation, where he asserts that drawing on different cultural practices in analyzing translations "means embedding cultural forms and practices in historical narratives which are thick with archival detail, but called forth by the present" (Venuti, 1992: p.10). Yet what remains important here is the historicity of the researcher. According to new historicists even the commentator himself is conditioned by the historical moment in which he lives. Hermans extends this argument to translation scholars drawing on the concept of Venuti's "domestic representations" that determine the interpreter's view about the nature of translation, norms, etc. (see relative autonomy below) (Hermans, 2003: p.382).

\subsection{Narratives of Translation}

As regards translation history, scholars have not ignored the fact that in writing histories of translation the historian encounters some theoretical problems. Paul Bandia deals with the issue of postmodernist historiography from a methodological perspective in his "The Impact of Postmodern Discourse on the History of Translation". The cline on which different approaches to translation are positioned is the one that begins from reconstructionism through constructionism to deconstructionism. ${ }^{\text {vi }}$ The consequences of the postmodernist or deconstructionist approach to history can be immediately seen here: the accounts of the past are mere representations. 
Lawrence Venuti has also contributed to the debate in his article "Translation, History, Narrative". History of translation, he argues, "like any history, endows translation practices with significance through a specific narrative form or mixture of forms" (p.812). Relativism characteristic of historicism is evident where he asserts even the very definition of translation is subject to historical context. He assigns a relative status to translation that is neither an original in the target language nor an original in the source language, but in fact a relatively autonomous text (ibid, pp.800-801). Based on relative autonomy, he argues that "the precise relationship between a translation and a foreign text has been the object of historically variable accounts" (ibid: p.801). He conceptualizes two sets of relationships that determine how far a translation is autonomous from its original: synchronic and diachronic. When a translation is considered from the first perspective it is thought to be "occup[ing] a position in contemporaneous hierarchies of cultural materials and practices" (ibid.). The second dimension is pertinent when a translation "enters into a relation to past materials and practices" (ibid.). With these relationships in mind one can see how a canonical definition of translation holds. A telling example of this kind of historical relativism is Abbe Prevost's "translation" of Samuel Richardson's Pamela, in preface to which he assumed, in Venuti's words, "an accurate translation conformed as much as possible to the foreign author's 'intention' and verbal 'manner' or style" (ibid: p.802). He reduced the novel to lesser volumes, omitted and manipulated the text flagrantly according to the "interpretation" he had of the book yet called his version a "translation". vii "A French translator today", Venuti concludes, "might also ground a claim of accuracy on such categories as authorial intention and style, yet with the very different argument that a translation can conform to them only by rendering every word that the foreign author included in the foreign text" (ibid.).

Also Venuti's account of translation in the Anglo-American context harks back to the Foucauldian tradition. His The Translator's Invisibility: A History of Translation uses a genealogical approach to translation practice that rejects teleology and objectivity ${ }^{\text {viii }}$ (p.39). Genealogy, as opposed to teleology, is a form of historical representation that illustrates a "discontinuous succession of division and hierarchy, domination and exclusion, which destabilize the seeming unity of the present by constituting a past with plural, heterogeneous meanings" (ibid.). The deconstructionist, postmodernist trend of skepticism toward the historical truth can be seen here. The historical representations are for Foucault "a cultural political practice" and a genealogical approach is "unique in affirming the interested nature of its historical representation" (ibid.). It is against such a background that Venuti explains in the following pages his methodological approach to translation history: he claims the book will "intervene[...] against the translator's situation and activity in contemporary Anglo-American culture by offering a series of genealogies that write the history of present" (ibid, 40). His aim is to search "the past for alternative theories and practices" in translation traditions (ibid.). He begins with this assumption that translation is marginalized in the context of the Anglo-American culture (and by extension, we might say, in many other cultures), rendering the translators "invisible", the term he uses throughout his poststructuralist and Marxist project. Douglas Robinson comments on Venuti's historicism:

Venuti's historicizing discourse is so fluent that it is extremely difficult to remember his intended heterogeneity. The book is argumentatively counter- hegemonic, tracing the suppression of dissident voices under the dominant regime of fluency, but rhetorically quite hegemonic, undermining dissident claims by suppressing its own centrifugal impulses, its own polyvocity, its own stammers and stutters and lost trains of thought. (Robinson, 2001: p.103)

As for the "(in)visibility" of the translator in the Anglo-American culture, Venuti traces (as was mentioned above) the discourse on and of translation in this context to reveal when the transparent discourse surfaced for the first time and marginalized the strategy he favors most in the contemporary situation, i.e., "foreignizing". He does this by revealing the major breaks in English translation history like Ezra Pound's translations from Chinese.

\subsection{Translation and Representation}

In studying the works of those authors that fall in the realm of history, particularly postmodernist history, we are actually dealing with translation as "a historical process" (Howland, 2003: p.48). The works mostly associated with this kind of approach is Niranjana's Siting Translation: History, Poststructuralism, Colonial Text that is concerned with the issue of representation. Howland believes that since colonial powers ${ }^{\text {ix }}$ have representation at their own behest they are in "a position to construct the forms of indigenous and subject identity" (ibid.), but according to the postmodernist skepticism regarding the issue of textual and historical representation we would better cast doubt on such a representability: "Informing this metaphorical equation between textual representation and the historical experiences", Howland asserts, "is a principle of mimesis - that texts mirror historical events" (ibid.). This approach runs the risk of reducing experience to meaning (Toew in Howland 2003: p.48).

Niranjana discusses William Jones' translation of laws of Manu "as a means of providing the Indians with a coherent set of their own rules" (ibid, p.49). She believes that Jones was not expressing the desires of British Empire, instead, his "remarks about the pagan Indians as impure, disgusting, and so on, are constitutive representations of Indians" (ibid.). As is clear in the statements above, textual representation replaces the reality, that is, these narratives of the colonized are (mis)taken for the lived experience. The principle that new historicists are against, namely, that the texts sufficiently represents the world is evident here. Here, it is translation, rather than an original, that is implicated in history and is an inevitable part of that history. In other words, for history to be completed, dealing with translations is necessary. 
Niranjana's project rejects teleology (as well as representability and objectivity) when she rejects "the focus on origins and embedding of events in predetermined or progressive histories" (ibid, p.50).

Niranjana's work is significant for our purposes in another way as well. She begins her book with an anecdote, a clearly non-literary piece (in the conventional meaning of the term) from Charles Trevelyan's On the Education of the People of India. The quotation is about the Indian boys begging for English books every passenger who gets off a ship (Niranjana, 1992: p.1). What we see here is a juxtaposition of literary and non-literary texts to find the power relations, or more properly asymmetric power relations, at work in the colonial context. The representation of the colonized is evident in the discourse employed by Treveylan and William Jones discussed above. She similarly argues "What is at stake here is the representation of the colonized, who need to be produced in such a manner as to justify colonial domination, and to beg for the English book by themselves" (p.2).

In her article "Censorship as Cultural Blockage: Banned Literature in the Late Habsburg Monarchy" (2002), Michaela Wolf draws on the concept of "cultural blockage" introduced by Stephen Greenblatt and the constructed-ness of identities in a culture. She takes Habsburg monarchy as a case to apply her model and claims at the outset that she "will analyze some agents in force within the translation process as well as the moments when blockage mechanisms become effective" (p.47). The Habsburg considered Italy an Other and tried to censor its image through complex selection machinery and paratextual strategies. Those in charge of selection and delimiting the account of the Other are patrons, publishers and, as a result, translators themselves who are involved with a sort of self-censorship (p.49). After classifying translations in a certain historical period as texts which could unsettle the construct of Italy in Austria and texts which were "harmless", she uses a statistical methodology and comes up with this point that translations belonged mostly to the latter group:

It can be said that Italian publications written for entertainment and that conserved an image rooted in the Renaissance and Romantic periods were selected at the expense of contemporary publications reflecting political and social realities that were blocked. (p.51)

She then analyses some instances of cultural blockage in translational interactions between the Habsburg and Austria using the "the discursive strategies adopted in paratexts" (p.55). She draws on Greenblatt, claiming that "the strategies adopted in the encounter of cultures heavily marked by asymmetrical power relations either lead to the acceptance of the Other in the Self and the Self in the Other or to the explicit articulation of the radical differences between these cultures" (ibid).

In another article by the same author ("Cultural Pluralism through Translation? Imagining the Italian Other in the Habsburg Monarchy") we see the issue of representation of the Other at the heart of the matter. In this piece she evaluates the translation practices under the same monarchy but here she juxtaposes literary and non-literary texts or historical and literary texts. "The image of Italy in the Habsburg Monarchy in the late nineteenth century", Wolf argues,

can be regarded as a mixture of the images produced in the various preceding historical periods. The image produced by Goethe's Italian Journey was still present and was gradually — although timidly — being interlaced with images determined by persistent political and ideological tensions between Italy and the Habsburg Monarchy. (Wolf, 2001: p.166)

After conducting a quantitative and qualitative research she concludes that "The choice of the titles banned clearly reflect the image of the Other that is not admitted". She gives the themes that were likely to be filtered through the choice and exclusion mechanism:

political ideas which (especially after 1866) mirror developments in the new Italian realm; other, more radical, political ideas closely related to the advent of socialist and anarchist ideology; publications generally aiming to empower the working class or the most underprivileged people; texts which recall the process of the Italian independence from Austria; any sort of writing against the Catholic Church; and texts rooted in Italian patriotism. (p.177)

As is underpinned by Wolf, all these activities arise from the socio-cultural milieu and reflect, either in macro or micro analysis, the ideology that shaped them.

\subsection{Translation as "Laboratory"}

Translations provide the cultural historian with concrete points of departure that can be used as a touchstone against which the work can be read in order to bring out the workings of ideology in a certain moment in history (or "episteme" in Foucauldian terms) as is captured in the "translation turn" in cultural studies introduced by Susan Bassnett (1998). Thus, translation can be looked at from two angles; as an object of study for its own sake (where the influence of culture on translation is emphasized); as a text that can make visible for us the power relations inherent in any text (this, of 
course, might be opposed to the cultural materialist practice of studying and stressing canons) or as an object of study in cultural projects. The former is realized in the "cultural turn" in translation research and the latter in Bassnett's call for "translation turn" in cultural studies. This provides "laboratory situations" for cultural researchers:

Translation provides researchers with one of the most obvious, comprehensive, and easy to study "laboratory situations" for the study of cultural interaction. A comparison of original and translation will not only reveal the constraints under which translators have to work at a certain time and in a certain place, but also the strategies they develop to overcome, or at least work around those constraints. This kind of comparison can, therefore, give the researcher something like a synchronic snapshot of many features of a given culture at a given time. (Bassnett and Lefevere, 1998: p.6, our emphasis)

The time and place mentioned above are the major assumptions in new historicism when it has it that every textincluding translation —is the product of a time and space within which the text is embedded. ${ }^{\mathrm{x}}$

\section{Conclusion}

As was implied throughout the paper, new historicism with its sophisticated interest in Foucault, Geertz and some other thinkers caused translation research to move to more sophisticated and rigorous frameworks. As was mentioned at the beginning of the paper, the advent of historically oriented thinking in translation obviated those conceptualizations that were supposed to be eternally valid. Linguistics-oriented approaches to translation were now criticized for their positivistic view. More than that: Lefevere (1995: p.8) sees "unhistorical" theories like New Criticism and, by extension, linguistics as impediment to the development of translation studies as such. As is clear here there is a parallel pattern of development in both literary and translation studies: from formalism to new historicism in literary studies and from linguistically oriented to a historically and culturally oriented approach in translation research. With these developments Translation Studies is expected to contribute to cultural studies because it is able to provide researchers with rigorous tools to understand culture and cultural interactions.

\section{References}

Bandia, P. (2006). The Impact of Postmodern Discourse on the History of Translation. In G. Bastin, \& P. Bandia (Eds.), Charting the Future of Translation History (pp.45-58). Ottawa: University of Ottawa Press.

Bassnett, S. (1998 ). Translation Turn in Cultural Studies. In S. Bassnett, \& A. Lefevere (Eds.) Constructing Cultures: Essays on Literary Translation (pp.123-140). Clevedon: Multilingual Matters.

Bassnett, S, and Lefevere, A. (1998). Introduction: Where Are We in Translation Studies? In S. Bassnett, \& A. Lefevere (Eds.), Constructing Cultures: Essays on Literary Translation (pp.1-11). Clevedon: Multilingual Matters.

. (1990). Introduction. In S. Bassnett, \& A. Lefevere (Eds.) Translation, History, Culture (pp.1-24). London and New York: Pinter.

Brannigan, J. (1998). New Historicism and Cultural Materialism. New York: St. Martin's Press.

Brooker, P. (2003). A Glossary of Cultural Terms. London: Oxford University Press.

Coldiron, A. (2001). Toward a Comparative New Historicism: Land Tenures and Some Fifteenth-Century Poems. Comparative Literature. 53(2), 97-116.

Diengott, N. (1998). Poetics. In P. Boiussac (Ed). Encyclopedia of Semiotics (pp.495-498). Oxford and New York: Oxford University Press.

Hamilton, P. (1996). Historicism, London: Routledge.

Hermans, T. (2007). Literary Translation. In P. Kuhiwczak, \& K. Littau (Eds.) A Companion to Translation Studies (pp.77-91). Clevedon: Multilingual Matters.

. (2003). Cross-Cultural Translation Studies as Thick Translation. Bulletin of SOAS. 66(3). 380-389.

Howland, D. (2003). The Predicament of Ideas in Culture: Translation and Historiography. History and Theory. 42 (February), 45-60.

Lefevere, A. (1995). Introduction: Comparative Literature and Translation. Comparative Literature. 47(1), 1-10.

Malpas, S. (2004). Historicism. In S. Malpas, \& P. Wake (Eds.) Routledge Companion to Critical Theory (55-65). London and New York: Routledge.

Montrose, L. (1998). Introduction: "Professing the Renaissance: The Poetics and Politics of Culture". In J. Rivken, \& M. Ryan (Eds.) Literary Theory: An Anthology (777-85). London: Blackwell.

Niranjana, T. (1992). Siting Translation: History, Post-structuralism and the Colonial Text. Berkeley, CA: University of California Press.

Pieters, J. (2000). New Historicism: Postmodernist Historiography between Narrativism and Heterelogy. History and Theory. 39(1), 21-38. 
Robinson, D. (2001). Who Translates? Albany: State University of New York Press.

. (1997). What is Translation? Centrifugal Theories, Critical Interventions, Kent: Kent State University Press.

Selden, R, Widdowson, \& Brooker, P. (1997). A Reader's Guide to Contemporary Literary Theory. (4 ${ }^{\text {th }}$ ed). London and New York: Prentice Hall.

Venuti, L. (1992). Introduction. In L. Venuti, Rethinking Translation (1-17). London and New York: Routledge. . (1995).The Translator's Invisibility: A History of Translation. London and New York: Routledge.

(1998). The Scandals of Translation: Towards an Ethics of Difference. London and New York: Routledge. (2005). Translation, History, Narrative. Meta. L(3), 800-816.

Wolf, M. (2001). Cultural Pluralism through Translation? Imagining the Italian Other in the Habsburg Monarchy. TTR. 13(1), 159-190.

. (2002). Censorship as Cultural Blockage: Banned Literature in the Late Habsburg Monarchy. TTR. 15(2), 45-61.

\section{Notes}

${ }^{\mathrm{i}}$ Pieters associates this trend with Foucault, and the heterlogical with Michel de Certeu (ibid.).

${ }^{\text {ii }}$ Greenblatt, the pioneer of new historicism, uses the anecdotal method to create a historical narrative that overcomes the problem of "the impossibility of encountering the past in its full immediacy" (Pietres, 2000: p.38).

iii T.M. Tillyard's The Elizabethan World Picture is a telling example of this kind of approach (Malpas, 2004: p.61).

${ }^{\text {iv }}$ There is a school in translation research which resembles this line of thinking called the Manipulation School This school in translation research is mostly associated with Itamar Even-Zohar, Gideon Toury and Theo Hermans. It can be associated with the new historicism, I think, because it emphasizes target culture and deems the translation text as a text in itself that can be implicated in power relations.

${ }^{\mathrm{v}}$ Bassnett and Lefevere criticize positivism inherent in linguistics. Positivism, they believe, tends to ignore relativity (1990: p.3).

${ }^{\mathrm{vi}}$ Bandia borrows all this from Alun Munslow who assigns these meanings to the terms employed: reconstructionism pertains to a "belief that truthful meaning can be directly inferred from primary sources" (Bandia, 2006: pp.46-47), constructionism to "a subspecies of reconstructionism but with the recognition of the frailty" of reconstructionsim (ibid., p.47) and deconstructionism to a school that "is critical of traditional assumptions of empiricism" (p. 47).

${ }^{\text {vii }}$ This is not to say that interpretation is an unacceptable move by the translator. Actually, translating is interpretation. The point that Venuti makes here is about the canons of accuracy and the degree of departing from the author's wording that changes historically.

${ }_{\text {viii }}$ This looking for the other of history reminds us of the heterological trend that Pieters associates with de Certeu (see heterology above).

${ }^{\text {ix }}$ The difference between colonialism and post-colonialism is that the latter is "the study of the ideological and cultural impact of western colonialism and in particular of its aftermath - whether as a continuing influence (neocolonialism) or in the emergence of newly articulated independent national and individual identities" (Brooker, 2003: p.198). Niranjana's work discusses the colonial context from a modern perspective, thus it can be considered post-colonialist in terms of the definition above.

${ }^{\mathrm{x}}$ A good example for the implication of translation in history and "laboratory situations" is Niranjana's work discussed above. 